\title{
The Implications of the Development of a "Market Place" in Education for the School Leader
}

\author{
Li-Na ZHANG* \\ Teachers' College Shenyang University Shenyang City, Liaoning Province, China \\ 1402678739@qq.com \\ ${ }^{*}$ Corresponding author
}

Keywords: Marketing, School market, Private education.

\begin{abstract}
Since the early 1980s market place in education has been the focus of attention, especially the introduction of a competitive environment is not limited to the United Kingdom, but also the United States, where schools now have to compete for students. At the same time this competition within education is spreading to other countries. Schools have to exist and survive within a competitive marketplace. So the methods used to promote the product are becoming more and more important.

The focus of this paper is to examine the ways in which a school markets itself and its 'product'. A case study in China is used for this purpose. The paper examines why schools engage in marketing activities, what methods they use to do so and what the main outcomes of those activities are for these schools.
\end{abstract}

\section{Introduction}

This paper has four parts. Part 1 is literature review, relating to the concepts of marketing and education, the rationale of marketing in education, the aims of school marketing and the rationale of marketing strategies in education. Part 2 displays the case study of the marketing practice in schools in China. Part 3, the conclusion, relates the evidence from the literature review and findings from the case study of schools in China.

\section{Literature Reviews}

\section{Marketing in General and Marketing In Education}

Many definitions of marketing have been proposed by various authors, and they encompass a number of different viewpoints.

Kotler and Fox (1985:7) define marketing as 'the analysis planning, implementation, and control of carefully formulated programs designed to bring about voluntary exchanges of values with target markets to achieve institutional objectives. Marketing involves designing the institution's offerings to meet the target markets' needs and desires, and using effective pricing, communication, and distribution to inform, motivate, and service the markets'. This definition concerns not only the managerial process of marketing involving analysis, planning, implementation and control, but also the role marketing plays in practical marketing problems.

Undoubtedly, marketing has entered the literature and practice of education in 1980s. In schools a largely acceptable definition of marketing is that marketing is the management process of identifying and satisfying the requirement of consumers and society in a sustainable way (Evans 1995:4). The focus point in this definition is not only filling the needs of consumers, but those of society as a whole, involving diagnosing needs and values, developing appropriate responses and then ensuring that those responses are meeting the needs identified. Marketing is not the answer to all a school's problems, but it can go a long way to reducing them (Evans 1995:5).

\section{Why is There Marketing in Schools?}

The move of the introduction of a market to education have been made in many of the developed 
countries, such as the United Kingdom, New Zealand, Australia, the United States as well as Canada over a decade. The reasons for this move are quite complex, Florestano (1 991) and Lewis (1993) gave a general idea of that: Nationally, there is increasing sentiment that many governmental services should be privatized because of a lack of confidence in public sector monopolies and concern that the government is controlling too much of our lives(cited in Jones 2000:2 1). Senge (1990) referred to business as the "locus of innovation in an open society' because it has a freedom to experiment missing in the public sector and often". In the nonprofit organization, criticism about education from public perception was that standards were falling and that schools were failing, although a rise in number of students taking ' $O$ ' and ' $A$ ' levels and going on to higher education. It was argued that the problem of it was that the over-bureaucratic system of school administration led to stagnation and a lack of accountability for improvement and local management was seen as one answer to the problem of lack of will to change.

Above all, a move from the administration of a school within a centralised bureaucracy towards devolved management to the level of the school with the concern for standards spread quickly in these developed countries. As Duffy (1990) puts it, 'LMS is about putting schools into the market-place, and the hard discipline of the marketplace is that the weak go to the wall' (cited in Wallance 1990:1 03). Heads will become, in effect, managing directors responsible for the way their schools perform, parents will become shareholders. (Hugill,1 989 cited in Wallance,1 992:1 02). For example, in the UK, an open enrolment and formula funding of the school have accompanied local management. The open enrolment gave parents the right to express a preference for the school they would like their child to go to and pupils can change schools if they are not satisfied. Schools now have to compete to attract pupils, because they are funded on the basis of the number of pupils they have enrolled. So there are clear advantages in attracting more pupils to a school. Schools have a greater autonomy with more responsiveness. In order to survive in the future, schools need to ensure a balance between quality or service and its customer and business needs as they have to attract pupils by providing what they require and keep on meeting those requirements.

All in all, open enrolment and enhanced parental power show an example of an attempt to create competition and build a market culture in the public sector. An increased emphasis on the importance of local school management and the delegation of significant responsibilities to head teachers suggest that the government is expecting this policy to achieve significant benefits in terms of raising educational standards and containing expenditure. The basic, practical reasons why schools need to adopt a marketing approach are brutally described by Davies and West-Burnhem (1991:1 45): While the main reason that a school should be marketing is a desire to improve its service and relationship with its clients, the main reason why it has to market itself is that, in 1990s, economic realities make this a precondition of its future survival.

\section{Who is School Marketing for?}

The question of who are the clients or customers in schoo1 marketing is the essential prerequisite for the effective marketing of schools, for schools exist to provide effective education for their clients (Davies et al 199 1:1 43). From the school's perspective, the pupils are likely to be seen as the direct consumers of the services being offered (Horn, 1987. cited in Wallance, 1992: 115), although some writers think that it is inappropriate for schools to treat their students as customers. Just as Pardey (1991 cited in Rix 1994:16) states that nevertheless, it is children that schools should be serving. Therefore schools should give a priority to satisfy the needs and wants of their students.

Another consensus about the clients of marketing schools appears to view parents as the main customer. It is these parents who have choices and shop around to get the education they feel is right for their children (Gold and Evans 1 998:68). Usually the parents' wishes decide the type of education and school their child attends, although the child's good or bad experiences may sometimes influence parental opinion. Last but not least, the wider community, which funds the school through local business rates and the community charge, also has a responsibility for the marketing of schools(Davies et al 199 1"1 42). In addition, there is a broader set of clients, who are the facilitators in the marketing of the school, such as central and local government bodies, 
ex-students, staff and employers.

\section{Marketing Strategies}

In business, marketing is usually divided into four sections, often called the four "P"s - product, price, promotion and place. These four elements are often referred to as the marketing mix (Bambooweb Dictionary).To obtain a sustainable competitive advantage, marketers will craft a marketing plan using the variables of the marketing mix, which must reflect the wants and desires of the consumers in the market. To determine what consumers want and desire, marketers will rely on marketing research to get information about it. Marketing management is referred to as the practical application of this process. Marketing of schools have adopted marketing techniques following the similar line with business. Put succinctly, Reeves and Chapel (1989, cited in Rix 1 994:20) relate the four " $p$ " $s$ to schools as follows:

1. Product -- the education offered to and achieved by the pupils

2. Price -- "value for money" in terms of the quality of education provided

3. Promotion -- how this product is presented to the customer

4. Place -- where the product (education) is provided

\section{Case Study---Marketing Practices in Schools in China}

All schools wish their consumers, such as pupils, parents, employers and communities to think positively of the schools and to be satisfied with their achievements. In the context of 'marketing' in schools, some ways in which schools market themselves can tackle this aspect by finding out what each of these of groups expects of the schools, and ensuring that the values of the school inform the action it takes to meet those expectations.

\section{Overview of Educational Reform in Recent Decades in China}

China's economic reform and opening up since 1978 has brought education into a new period of development. In order to contribute to the growth of a market economy, a structural reform in the educational field initiated in the mid-1980s and the general policies began a process of decentralization, instead of the monopolistic role of the state in education. More especially, because 'government control of schools was too rigid and management inefficient' (Hawkins:3), privatizing schools, decentralizing finances and management were regarded as a desired means of creating competition and building a market culture in order to improve the provision of schooling. China has made more efforts to privatization in schools and decentralization in special features of finance, management, and curriculum, etc. The strategies schools market themselves have been adopted in response to a market economy context.

\section{Private Education in China and Marketing Strategies of Schools}

Introducing the market economy in China creates a favorable environment for the emergence of private education (Mok,1 996.in Mok and Wat 1997:1 1). In the mid 1980s, under the Programme for Reform and the Development of China's Education, non-state run education institutions developed rapidly, ranging from kindergartens to colleges and universities in big cities. The emergence of private schools has infused the competitive forces of the market place between state schools and private ones as well as privates themselves. Just as Labaree (1997:3 8) suggested that "The resent push of educational choice,...is the strongest educational reform movement of the 1 990s, and it is grounded entirely within the consumer-is - king perspective"(cited in Jones,2000:2 1). Satisfied customers, such as students, parents, employers and community, are the best marking assets a school has(The LMS Initiative.1 990:1 60). Therefore, to survive and develop in these harsh competitive circumstances, heads of schools have planned to attract students by providing good quality education and schools' excellent reputation.

Firstly, heads or principals have put their priority as the needs of both students and the market and these have become the aims and values of the schools. To keep up with the new market context, schools all adopt a more flexible approach in developing more practical and market-driven 
courses and thus their curricula are practically oriented. Foreign languages and computer training, as well as artistic and practical subjects are emphasized in these private schools. In addition, considering students' choice and needs, heads or principals have adopted a customer-oriented approach to running their educational services. Furthermore, it is believed that excellent teaching qualities can help to enhance the status of the schools which would greatly help to attract funding from different sources, such as the government, the business enterprises and the public. Their second priority is to communicate the link between quality and marking. Personal commendation about what a school has done for them will achieve more than the glossiest promotional campaign (ibid.). So certainly many schools have enthusiastically embarked on their contact with parents, employers and community, displaying their aims and values as well as their achievements to attract additional pupils, even offering free gifts to them. In addition, another desirable asset of schools is to establish good working relationships with the media, especially local newspapers, and TV stations. It is no doubt that what the papers say and TV stations show is of paramount importance to schools' images. Furthermore, many heads also consider the logo of schools on uniforms as a means of displaying the school image.

\section{Finance and Management in Marketing of Public Schools}

Decentralization in finance and management from the central to local even to individual schools was another key reform effecting educational structure in China. This decentralized management has put schools into the market place. In addition to attract students, school heads must attract different kinds of funding and financial support to carry on their activities. By becoming more marketing oriented, heads of schools have adopted a strategic marketing approach to generate income in order to solve the problem of the increasingly diminished finance support from government. Multiple channels for the financing of schools have been adopted in schools, such as individual donors, overseas donations, tuition fees, local community revenue, income from business enterprises to fill in the gap left by the central government and local government (Mok, 1998 cited in Hawkins: 8). Through collaboration with the public, government and industries, providing social services and commercializing technological research findings as well as transferring scientific products to market have become the major means of the universities to attract the public donation, state and local governments' funding and industries' finance support. The last but not least, student tuition fees and accommodation fees, continuous adult education fees are all indispensable income to universities. In primary and secondary schools, to accumulate sources of financial support, the school's head or director of development is usually responsible for fund raising. In addition, many schools have tried to run enterprises and engage in the commercial and business activities to support schools' finance.

\section{Implications from Case Study}

The 'Market Place' in education in China is developing rapidly under the dominant political-economic climate and the favourable policy environment. Market forces directly influence the planning of these commercially-oriented programmes in schools. Profit maximisation and customer satisfaction have become fundamental performance indicators which are similar to other enterprises in a business environment.

It is obvious that heads or principals of schools have, to a great extent, become corporate entrepreneurs, responsible for the overall marketing programs. So the ability to be proactive in a different external environment and to develop internal unique characteristics is important for heads or principals of schools to achieve their strategic objectives. That is also the crucial determinant for a school to decide the extent to which it is able to project and market itself in the market place in education.

\section{Conclusion}

The literature review identified the bottom-line aspects of 'market place' in education. From the case study, it is evident that marketing is a real and relevant issue in educational organizations. It is 
clear that schools have been more active in involving themselves with the market place. Most schools are giving attention to the necessity of marketing themselves. 'To be commercial survivors', schools have to understand the dictates of commercialism. They had understood that to survive in the educational marketplace where the consumer can exercise freedom of choice necessitated an absolute knowledge of what the consumer actually wanted (Maker 2001.cited in Fairbrother.2002:54). The messages and images are projected by a marketing strategy in schools for student recruitment. Furthermore, schools also have a focus on teaching quality and students' choice, with the implication of widening participation in internal competition and improving educational quality in order to enhance the reputation of schools and also attract customers as well as fund raisers. In some senses, schools have been valued in the marketplace as an economic entity, because many schools have tried to run enterprises to obtain their income.

It is the question here generating from the paper that to what extent marketing will influence the model of education in the future. It may be as Webster (1994) has indicated, marketing as an integral part of management requires 'ongoing maintenance and investment". "there can be no turning back" (cited in Rix, 1994:61). So the ways schools "market" themselves also require further research and study to keep abreast with the development of the marketplace in education in the future.

\section{References}

[1] Ainley, R 1990.Training Turns to Enterprise."Vocational Education in the Market Place. Hillcole Group Paper 4 The Tufnell Press, London.

[2] Bambooweb, Marketing, http://www.bambooweb.com/articles/m/a/Marketing.html.

[3] Cave, E. and Wilkinson, C.(Ed.)1 990.Local Management of Schools Some Practical Issues. Routledge.

[4] Circle, April 1 998.Main Findings of the Good Practice Guild on Marketing The Further Funding Council.

[5] Davies, B., Ellison, L., Osborne, A. and West- burnham, J. 1991.Education Management for the 1990s.Longman.

[6] Davies, B. and West-Burnham, J. (Ed.) 2003.Handbook of Educational Leadership and Management Pearson Longman.

[7] Evans, I.1995.Marketing for School. Cassell.

[8] Fairbrother, K.J. 2002.Marketing the Independent School The School of Education of the University of Bristol.

[9] Gold, A. and Evans, J. 1998 Reflecting a School Management London: Falmer Press.

[10]Hawkins, N. J. Centralization Decentralization Recentralization: Educational Reform in China University. of California Los Angeles.

http://wwwl.worldbank.org/education/globaleducationreform/pdf/hawkins:pdf.

[11]ones, A.B.(Ed.)2000.Educational Leadership Policy Dimensions in the 21 Century. Ablex Publishing Corporation Stamford, Connecticut.

[12]Kotler, E and Fox, K. 1985.Strategies Marketing for Educational Institutions Prentice-Hall, INC., Englewood CRffs, New Jersey 07632.

[13]Mike, R. 1994.Marketing the Primary School and the Role of the Head The School of Education of the University of Bristol.

[14]Mok, K. and Wat,K. 1997. The Merging of the Private and Public boundary. " Education and the Market Place in China. http://www.cityu.edu.hk/sa/working paper/wp9703.pdf 
[15]Preedy, M. Glatter, R. and Levacic, R. 1998. Educational Management Strategy Quality, and Resources. Open University Press Buckingham Philadeliphia.

[16]The LMS Initiative.1990. ( $2^{\text {nd }}$.Edn.) Local Management in School A Practical Guide. The Chameleon Press Ltd.

[17]Wragg.T.1988. Education in the Market Place The Ideology Behind the 1988 Education Bill The Jason Press.

[18]Wallance. G (Edited). 1992. Local Management of School Research and Experience. Multilingual Matters Ltd Clevedon Philadelphia Adelaide.

[19]Wallance. G 1 993.(Edited).Local Management Central Control Schools in the Market Place. Hyde Publications. 